\title{
地理情報システムとリモートセンシングによる 石川県白峰村の出作り地の自然環境解析と適地分析
}

\author{
朴 舜燃・岩田 憲二・安仁屋 政武 \\ Analyses of the Physical Environment and Preferred Sites of Dezukuri in \\ Shiramine,Ishikawa, by Geographic Information Systems and Remote Sensing. \\ Soonchan PARK,Kenji IWATA and Masamu ANIYA
}

\begin{abstract}
Dezukuri", which used to be the main subsistent farming type in the Hakusan area, Ishikawa Prefecture, has rapidly disappeared during the 1950s and 1960s, due to the fuel revolution and the high ecomonic growth rate. At present, it is on the verge of the total extinction. In this paper, we analyzed the physical environment of the "Dezukuri" in Shiramine Village utilizing geographic information system (GIS) and remote sensing techniques. Based on the distribution map of the Dezukuris plotted at a sale of 1:5,000, in which 322 Dezukuris were identified with a total area of $1.39 \mathrm{~km}^{2}$, we analyzed their location by superimposing the Dezukuri distribution map with maps of altitude, slope gradient, slope aspect, drainage systems, landslides, logging roads, geology, soil, vegetation, and the planting practice. Their preferred sites are found to be 600 to $900 \mathrm{~m}$ in elevation, $15^{\circ}$ to $20^{\circ}$ in slope gradient, and the east aspect of the slope, in the areas of conglomerate-sandstone, brown forest soil and the white oak community.
\end{abstract}

Keywords:白峰村(Shiramine village), 出作り (Dezukuri), リモートセンシング(Remote sensing), 地理 情報システム(Geographic Information System)，適地分析(Analyses of preferred site)

\section{1. はじめに}

石川県の白山西槐は雪深い地域であり，植物・動 物の採集・捕獲と自然の原野を伐り開いて農業を営 むナギ畑を有機的に結びつけた居住システムである 出作りが，この地域の主な生業で随所に見られた。

白山麓には 1 町 5 村と呼ばれる石川郡を構成す る, 鶴来町, 河内村, 吉野谷村, 鳥越村, 尾口村, 白峰村がある。その中でも白峰村は，一番面積が大 きい村で，出作りも一番多く分布していた村であ る.

山岳農業形態の一つである“出作り”は，夏期に 山中, 冬期に本村で生活する季節出作りと，一年を 通して山中で生活する永住出作りの二つの形態があ る. 季節出作りは，雪が融け始める4月頃から雪が降 り始める11月頃（夏期）に母村を離れ，家族そろっ て山中の出作りイエ，出作りウチと呼ばれる施設に 居住し，ここを拠点として周囲の山地斜面でナギ八

朴： テ305 茨城県つくば市天王台1-1-1 筑波大学大学院地球 科学研究科 Tel:0298-53-6853

Graduate Student, Geosience Program,Universty of Tsukuba,1-1-1 Tenoudai,Tsukuba,Ibaraki 305,Japan
夕や養蚛などを行う(岩田，1984). 雪で農業ができ ない11月頃から4月頃（冬期）までは，山を下りて母 村で生活する。こうした季節出作りは石川県の白峰 村を中心として1960年代まで活発に行われていた が，高度経済成長と燃料革命により衰退の一途をた どり，現在はほとんどなくなっている.

これまで白山山麓の出作りに関していくつかの研 究があるが（田中・幸田,1927a,b;加藤,1935;千葉,1984; 矢々崎,1981,1983;岩田,1984,1985,1987,1988,1989,1990; 安仁屋,1994a,b,1995）, 小縮尺の地図を用いて, 出 作りの経営や農業生産に関して述べられたものが多 く，出作り地の分布に関する詳細な研究はほとんど 行われていない，安仁屋(1995)は白峰村の1912年と 1953年の出作り地の分布図を作成し，その自然環境 と跡地の変化を整理した．しかし，それは旧版の地 形図に示されている山間部の畑を出作り地として見 なしており, その縮尺も5万分の1であるため, 出作

り地の位置，また数や面積が正確とは言えない。

本研究は，5千分の 1 の大縮尺の地形図に示された 白峰村の出作り地分布図をもとに，地理情報システ ム(ARC/INFO)とリモートセンシングデータを使っ 
て出作り地の自然環境を解析し，適地を抽出すると ともに，放棄された出作り地がどのように変化した かを明らかにすることを目的とする。

\section{2. 対象地域の概要}

白峰村は白山 $(2,702 \mathrm{~m})$ の北西斜面に位置し，その 面積は $222 \mathrm{~km}^{2}$ であり，本村の標高は約 $500 \mathrm{~m}$ であ る。村全域が山に囲まれていることから，手取川の 本流または支流に沿った河谷平野や河岸段丘上の小 規模な平垣面に集落を形成し，この集落を母村とし て, 山地斜面で出作り耕作を行っていた。周辺に は，北に金沢，西に小松市，南に勝山，大野などの 都市があるが，東㑡は非常に山が険しいうえ急流が 流れているため, 白川村のみで大きな町はない（図 1).

多雨多湿な北陸型気候区のなかでも，険しい地形 環境によって, 全国的にも有数の深雪地帯となって いる. 年平均気温は $13^{\circ} \mathrm{C}$ 前後で, 1 月に最低を示す. 降水量は3,300 mm近い值で, 冬季にピークがあり, 平均最深雪量は $3 \mathrm{~m} ら 4 \mathrm{~m}$ である.

人口は1955年には約4,300人であったが，その後, 急激に隇少し，1995年11月現在には1,284人である。 地質は, 中生代の堆積岩である手取層(磷岩( II ), 磻岩・砂岩, 頁岩・頁岩砂岩互層)や第三紀の流紋岩 質凝灰岩が広く分布し，これを覆うように第四紀火 山岩が分布している。これらの岩石は崩れやすいの で土砂災害が発生しやすい。

土壤は, 褐色森林土壌やポドゾル土壤が多く分布 している. 褐色森林土壌は山地の中腹斜面から山麓 にかけて丘陵地に広く分布している。一方，ポドゾ ル土壤は白山山地を中心として分布している.

植物群落は, 多様な相観を示している. 高山の西 限になる白山を中心とした高山帯では，コケモモ． ハイマツ群集, 高山高茎草原, ショウジョウスゲ . イワイチョウ群集, アオノッガザクラ雪田群落など が見られる. 亜高山帯ではオオシラビソ群集やチ シマザサ・タケカンバ群落が代表的な植生である が, タケカンバを欠くチシマザサ群落，ミヤマハン ノキ群落などもみられる、いずれも自然植生であ り, 自然性の高い地域となっている. 丘陵上部から 山地带にかけてはブナ・ミズナラクラス域に属し,
ブナの自然林であるチシマザサ・ブナ群落が広範に みられ，豊かな植物相を育んでいる，また，尾根に はクロベ・ヒメコマツ群落, 谷沿いにはジュウモン ジシタ・サワグルミ群落が帯状に分布している.

\section{3. データ作成および解析方法}

使用した地理情報データは, 出作り地分布図, ディジタル標高モデル，水系図，地すべり図，地質 図, 土噇図, 植生図, 植林図, 林道図である。以下 にこれらのデータの作成方法について説明する。

\section{1. 出作り地分布图}

5 千分の1の森林基本図に位置が示されている白峰 地域の出作り地分布図(岩田, 1993作成)を基に，ス キャナーを使って読み込んだ1977年の空中写真上 で，出作り地を同定した。空中写真で判読困難なも のは，現地調查の結果を 5 千分の 1 の地図上にプロッ トし，GISソフトウェアARC/INFOとERDASを 使って入力した。 そして, 空中写真上で同定したも のと, 現地調査の結果を統合して出作り地分布図を 作成した。 これによると全体 322 力所, 面積 $1.39 \mathrm{Km}^{2}$

となった。しかし, 風嵐谷流域は未調查地域とし て残っているため，対象地域から除いた(図1).この 際, 出作り地の跡地の状況も入力した。

\section{2. 地理情垠データおよびリモートセンシンダデータ}

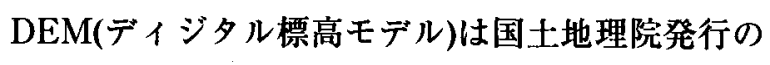
2.5 万分の 1 の地形図から $10 \mathrm{~m}$ ごとの等高線をディジ タル化して作成した. DEMからGISソフトウェア ARC/INFOを使ってTINを発生させ,TINから格子 配列のDEMに変換した。 そのDEMから高度図（50 $\mathrm{m}$ ごと), 斜面傾斜図 ( $5^{\circ}$ ずつ)，斜面方位図 (8方 位）を作成した。

水系図は 2.5 万分の 1 の地形図の上で, 谷を示す等 高線の届曲が $90^{\circ}$ 以下になるところまでを"谷”と定義 し作成した. 地すべり図は1947年米軍撮影の白黒空 中写真と 1977年撮影のカラー空中写真を判読して, 2.5 万分の 1 の地形図にプロットしたもの(安仁屋, 1994b)をディジタル化した。地質図と土壤図は経済 企画総合開発局が1974年に発行した土壤分類図に含 まれている20万分の1を，植生図は環境庁が 1975 . 
1976年に作成した自然環境保全調査報告書中の5万分 の1の現存植生図をディジタル化した。植林図 は石 川県森林事業所が1994年に作成した5万分の1を，林 道図は1977年のカラー杂中写真と 1990年の白黒空中 写真から1.25万分の 1 (2.5万分の1を 2 倍に拡大したも の)の地形図にプロットしたものをそれぞれディジタ ル化して使用した.

リモートセンシングデータは，1977年10月(1.6万 分の1,カラー), 1990年10月(1.5万分の1,白黒)， 1992 年 10 月( 2 万分の 1 ,カラー) の 3 時期の空中写真と, 1987年10月のLandsat TM（分解能30 m)，1988年 10月と 1991年8月のSPOT（分解能 $20 \mathrm{~m}$ ），1994年5 月のJERS 1 (Japanese Earth Resources Satellite, 分解能 $18 \mathrm{~m}$ )の衛星データである。

空中写真は，スキャナーを使って1977年のものを 読み込み，ERDASを利用して幾何補正した後, 特
定した出作り地を全体的に示すためにモザイクを作 成した. 幾何補正は 2.5 万分の 1 の地形図を使って行 い，地上基準点を15〜20点を選び，ピクセル・サイ ズ許容誤差を1にして，最近瞵法により行った(図 2).

衛星画像は, 個々の出作り地の規模はあまり大き くないうえ，その大部分が周囲の植生と混じり合っ ているため, 出作り地の判読にではなく全体の地形 や植生などの解析に使用した(図3).

\section{3. 解析方法}

出作り地の地形的な位置条件と自然環境を明らか にするために，ARC/INFOを用いて出作り地分布図 を上記の自然条件データと重ね合わせ，単純集計分 析を行った。これに基づき適地の考察および跡地の 変化を示した。

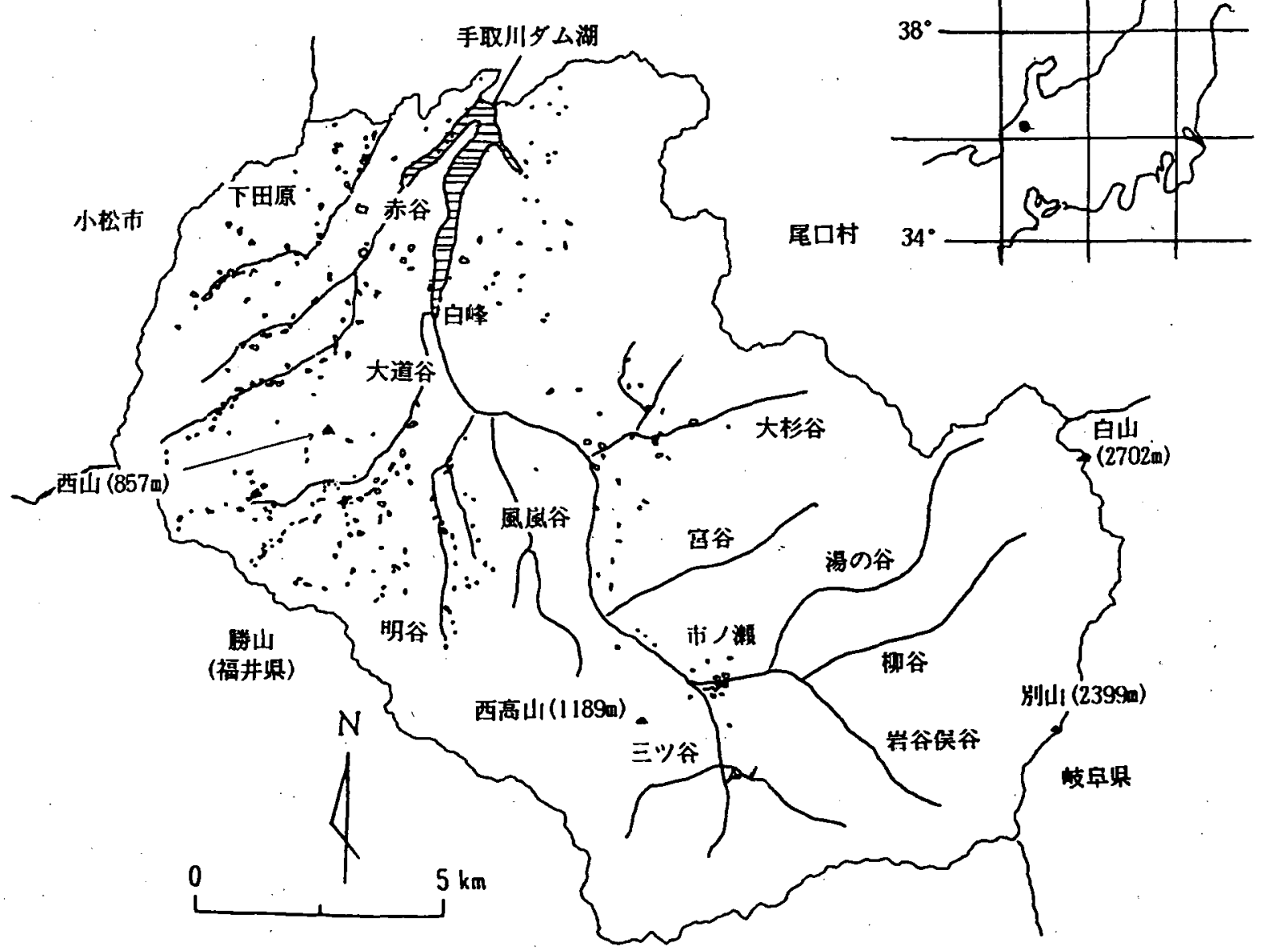

図1 白峰村の概要と出作り地の分布 


\section{4. 出作り地の環境解析}

\section{1 . 高度}

気温は高度と密接な関係があるので $\left(0.5 \sim 0.6^{\circ} \mathrm{C} /\right.$ $100 \mathrm{~m})$ ，高度は作物の生育に重要な影響を及ほす。 標高 $450 \mathrm{~m}$ から1,200 mまでの高度域について，50 m 間隔ごとの高度分布図を作成し，出作り地と重ね合 わせてみると(図4)，標高約 $600 \mathrm{~m}$ から900 mの間に出 作り地の約 $80 \%$ 分布し，面積で見ると標高約 $700 \mathrm{~m}$ から750 m付近に, 出作り地の数で見ると $850 \mathrm{~m}$ から $900 \mathrm{~m}$ 付近にピークがある(表1). 1,000 m以上の高度 ではその数や面皘が少なくなるが，それは地形条件 や気候的制約による作物栽培条件，そして明治以降 この高度域の林地が国有林に編入されたことによる もので, $1,000 \mathrm{~m}$ 付近が出作り境となっている.

\section{2. 科面傾斜}

対象地域を斜面傾斜 $0^{\circ}$ から $45^{\circ}$ まで $5^{\circ}$ 間隔に分け， $45^{\circ}$ から $90^{\circ}$ までを一つのグルーブにして出作り地と 重ね合わせてみると(図5)，10から $25^{\circ}$ までの傾斜に 出作り地の的70\%が分布していることがわかる．ま た，40 以上の急な傾斜には出作り地はほとんどない (表2).

\section{3. 斜面方位}

対象地域の斜面を8方位に分けて出作り地と重权合 わせてみると(図6)，日当たりが良い山地斜面の北東 から東，南東の方面に出作り地の $45 \%$ が位置してい る(表3)，斜面方位は日照時間の長さに関係があり， 日照時間は作物の発育と密接な関係がある。また， 日照時間によって栽培されたものも異なったであろ う.

\section{4. 水系}

出作り地分布図と水系図を重ね合わせてみると(図 7)，起伏が大きくない手取川の左岸㑡の支流である 下田原，赤谷，大道谷，明谷などに沿って出作り地 が多く分布していることがわかる。これらの地域は 堆積岩が分布し，地形は一般的に険しくない。 ま た，市ノ瀬，大杉谷の東㑡にも分布している。ここ は河岸段丘がよく発達している地域である。

\section{5.地すべり}

地すべり分布図を50 m間隔の等高線図と重ね合わ せてみると，斜面が地すべり地であることがわか る(図8).一般に地すべりによって急な斜面が緩くな り，地面の動きによって土壤が拱乱され周りに比べ て豊かになる，場所によっては地すべりの結果でき た粘土によって保水性が良く，山腹でありながら水 の便が比較的よくなることもある．対象地域の地す ベりはかなり古いものが多く，侵食されて滑落崖が 不明暸になっていたり，逆に滑落塊がなくなってい るものもある。このようなものは現在動きが止まっ ていると考えられる，実際，現在でも活発に動いて いる地すべりは少ない(安仁屋，1994b)，対象地域の 出作り地の79\%は斜面傾斜 $25^{\circ}$ 以下に位置している. 地すべり分布と重ね合わせてみると，出作り地の50 \%以上が地すべり地に含まれており，山腹の緩斜面 に分布していることがわかる。

\section{6. 地質}

地質と出作り地との関保をみると(四9), 約 $52 \%$ の 出作り地が磁岩・砂岩地域に分布し，約 $26 \%$ が頁 岩・頁岩砂岩互層地域に分布していることがわかる (表4).この地域に出作りが集中しているのは，農業 生産性の高さを求めたということよりは，嘫岩・砂 岩と頁岩・頁岩砂岩互層地域が占めている面皘が白 峰村全体面積の約 $72 \% て ゙ ，$ 幅広く分布しているから である。また，片麻岩質岩石，安山岩質岩石・灭碎 岩，結晶質石炭岩などの地城には出作り地はあまり み見られないが，それは高度と地形の険しさの問題 で，そこまで入るのが難しかったからだと考えられ る.つまり，地質は出作りの分布には直接関係がな かったと思われる。

\section{7. 土烄}

土壤と出作り地との関係をみると(図10), 褐色森 林土壌の地域に約78\%の出作り地が分布している(表 5). 出作り地の大部分は川治いに分布しているが, 褐色森林土壌も谷沿いに広く分布している。また， 褐色森林土裹は全体面積の約 $44 \%$ を占めているた め，此率が高いのは当然と言える．それに繞き，出 作り地は，湿性褐色森林土壌の地域に約 $11 \%$ ，乾性 
褐色森林土壤の地域に約 $10 \%$ が分布している.

\section{8、植生}

対象地域内の植生図に見られる29種の凡例の中, 9 種に出作り地は分布している(図11)。それはブ

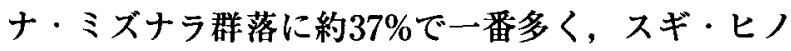
キ・サワラ植林に約 $26 \%$, チシマザサブナ群落に約 $21 \%$ ，ツルヨシ群落に約7\%の順になっている.

この四つの植生に出作り地の約 $92 \%$ が分布している (表6).この四つのカテゴリーの植生が全域に占める 割合は約78\%なので，このような植生のところが他 の要素と相俟って好んで選ばれたと解析できる.

\section{9.植林}

出作り地と植林分布を重ね合わせた結果，国有林 の中には全く分布してないことが判明した(図 12，表 7). その理由は，国有林地であるから入れなっかた というよりも，険しい地形，作物栽培の厳しさの影 隌の方がより強く作用していたためと考えられる. 保安林の地域には出作り地の約 $30 \%$ が分布してい る.

\subsection{0. 林道}

林道図と出作り地分布図を重ね合わせてみると画 者の関係が明瞭に見られる(図7)，林道は水系とほほ 一致しており，出作り地との間には密接な関係があ る. 石川県自然保護センター(1988)によると, 出作 クは自給的な生活と考えられがちであるが，現金収 入を得るために炭とか養蚕，あるいは杉苗とか山菜 作りなどをしていた。 そして，出作り地への出入り と作物の運搬のためにも道路は必要であった。しいか し，昭和30年代からの燃料革命と高度経済成長によ り炭が売れなくなり，その時点で出作りを含めて他 の生業も絶え始めた。

\section{5. 出作り地の分布の特徵と適地}

出作り地の分布と高度，斜面傾斜，斜面方位との 関係を見ると，出作り地の地形的適地が判明する. 高度約 $600 \mathrm{~m} \sim 900 \mathrm{~m}$, 斜面傾斜 $15^{\circ} \sim 25^{\circ}$, 斜面方 位北東から南東の間が出作りの適地であることがわ かる．それは，日当たりの良い条件と起伏が大きく
ない条件，高度による温度の変化が作物に与える条 件によるものと考えられる.

地質, 土壤, 水系との関係では, 磔岩・砂岩地 域，褐色森林土壤の地域に多く分布しいるが，これ らの面皘自体が压倒的に広い。また碟岩・砂岩地 域, 褐色森林土壤の地域はほとんど川と重なってお り，農業と水との密接な関係から，川沿いに分布す るのは当然と言える.

白峰村では周りの山のいたるところにスギの群落 が点在する．それは出作り地を放棄した当時の政府 の植林政策によって，スギが植えられた結果であ る. 褐色森林土壌の土地生産性は中程度であるが, スギには適している。 また，放棄された時期にもよ るが，放棄の当時何も植えなかった出作り地は周囲 の植生に同化されて区別がつかなくなっており，空 中写真だけでの判読は非常に難しい(表8).

出作り跡地の植生を見ると(表9), スギ群落が 165 カ所で全体の約 $51 \%$ 占めており, ブナ・ミズナ ラ群落やチシマザサ・ブナ群落が 134 カ所で約 $42 \% を$ 占めている。

出作り地のスギ群落は周囲の植生とは全く別であ り, 出作り跡地と判断する指標の一っとなってい る.

\section{6. おわりに}

本研究は 5 千分の 1 の大縮尺の地形図に示された出 作り地分布図をもとに地理情報システムとリモート センシング技術を使って出作り地の自然環境および 適地解析を行った。この際，問題となったのが使用 した地図の縮尺の差による結果の制的である．例え ば，出作り地分布図の縮尺が5千分の1である反面， 地質図や土壌図などは 20 万分の 1 なので出作り地の微 妙な立地条件はとらえられなかった。これらの紐か いデータの取得は地道な現地調査による他ないが, 㕕域を対象として，その自然条件を大きく捉えるの に地理情報システムが適していることが示された。

\section{謝辞}

本研究を進めるにあたり，データの収集や作成にご 支援下さった白山自然保護センターの野上達也氏, 石川県庁自然保護課の水野昭憲氏，（株）パスコの 
佐藤亮氏, 白峰役場と石川林業事業所, 農業環境技 術研究所の隔测研究室の皆様に感謝の意を表しま す. 本研究に使用したJERS-1のデータは「研究向け データ利用」として宇宙開発事業団から提供された ものである。「衛星データ所有：通商産業省／宇宙 開発事業団」，「衛星デー夕提供：宇宙開発事業 団」。

\section{参考文献}

安仁屋政武（1994a）白山地域の概要と自然『環境保全 型山村社会の環境条件と地域変容一石川県白山秕の 人·自然·環境問題一」,筑波大学 大学院環境科学 研究科白山グループ,1-18.

安仁屋政武（1994b）白山西䈭白峰村の出作り地の自然 環境とその跡地の変化一地理情報システムとリモー トセンシング解析による一、「環境保全型山村社会 の環境条件と地域変容一石川県白山麓の人 · 自然 · 環境問題一』，筑波大学大学 院環境科学研究科白山 グループ,19-31.

安仁屋政武（1995）白峰村の出作りの自然環境と適地の 変化,「アトラス-日本列島の㻴境化-』，朝倉書店,9091.石川県自然保護センター（1988）『白山簏自然 環境活用調查報告書』,1-64.

岩田憲二（1984）白峰村大道谷における出作り地の土地 利用について,「石川県白山自然保護センター研究 報告」, 10,111-119.

岩田憲二（1985）出作り地における食生活一白山秕の場 合, 「石川県白山自然保護センター研究 報告」 ,11,59-66.

岩田憲二（1987）白峰村大道谷における出作り分布の変 遷について，「石川県白山自然保護センター研究報 告」,14,107-117.

岩田憲二（1988）白峰村大道谷地区における出作り分布 の変㟟についてー桑島地区を例としてー，「石川県 白山自然保護センター研究報告」, 15, 107-116. 岩田害二（1989）白峰村南部地域の居住分布, 「石川県 白山自然保護センター研究報告」，16, 95-101.

- 岩田憲二（1990）白峰村明谷地域における居住分布に ついて,「石川県白山自然保護センター研究報告」 $, 17,61-64$.

加藤助参 (1935) 白山山麓に於ける出作り研究, 「京大農

業経済論集 第1集」,245-351.

田中啓爾・幸田清喜（1927a）白山山篦に於ける出作地 帯 (一)，「地理学評論」,3(4), 281-298.

田中啓爾・幸田清喜（1927b）白山山麓に於ける出作地 帶 (二), 「地理学評論」,3(5), 382-396.

千葉徳爾（1984）：山地住民の生業と流動生-一例とし
ての白山槐一,地方史研究,34-(4), 69-73.

矢々崎孝雄（1981）白山篦に於ける出作り地の地形と地 名,『地理学々地理教育』,古今書院, 402-412. 矢々崎孝雄 (1983) 白山秕白峰村に於ける出作り地の実

態「「石川地理」,1,3-14.

表 1 出作り地の垂直分布

\begin{tabular}{|c|c|c|c|c|}
\hline 高 & (a) & $\begin{array}{l}\text { 面 }\left(\mathbb{R} \mathrm{n}^{2}\right) \text { と } \\
\text { その合 }(x)\end{array}$ & 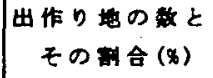 & 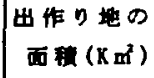 \\
\hline 460 & -500 & $1.4(0.6)$ & $0(0)$ & 0 \\
\hline 500 & -550 & $5.0(2.3)$ & $14(2.8)$ & 0.037 \\
\hline 550 & -600 & $6.5(2.9)$ & $42(8.5)$ & 0.121 \\
\hline 600 & -650 & $7.6(3.4)$ & $50(10.1)$ & 0.158 \\
\hline 650 & -700 & $9.8(4.4)$ & $69(13.9)$ & 0.217 \\
\hline 700 & -750 & $11.5(5.1)$ & $69(13.9)$ & 0.220 \\
\hline 750 & -800 & $11.0(5.0)$ & $63(12.7)$ & 0.149 \\
\hline 800 & -850 & $12.5(5.6)$ & $65(13.1)$ & 0.153 \\
\hline 850 & -900 & $15.4(7.0)$ & $74(14.9)$ & 0.218 \\
\hline 900 & -950 & $12.7(5.7)$ & $30(6.0)$ & 0.074 \\
\hline 950 & -1000 & 12. $3(5.6)$ & $14(2.8)$ & 0.038 \\
\hline 1000 & -1050 & $11.8(5.3)$ & $4(0.8)$ & 0.009 \\
\hline 1050 & -1100 & $11.1(5.0)$ & $1(0.2)$ & 0.003 \\
\hline 1100 & -1150 & $10.1(4.6)$ & $1(0.2)$ & 0.001 \\
\hline 1150 & -1200 & $9.5(4.3)$ & o( $\quad 0)$ & 0 \\
\hline
\end{tabular}

表 2 斜面傾斜別の出作り地の分布

\begin{tabular}{|c|c|c|c|}
\hline $\begin{array}{c}\text { 斜面㙋斜 } \\
\text { (度) }\end{array}$ & $\begin{array}{l}\text { 面程 }\left(\mathrm{Km}^{2}\right) \text { と } \\
\text { その合 }(x)\end{array}$ & $\begin{array}{c}\text { 出作り地のと } \\
\text { その請合 }(x) .\end{array}$ & $\begin{array}{l}\text { 出作り地の } \\
\left.\text { 面㮴 (K } \text { af }^{2}\right)\end{array}$ \\
\hline $0-5$ & $0.9(0.4)$ & $8(1.2)$ & 0.022 \\
\hline $5-10$ & $8.9(4.0)$ & $67(10.0)$ & 0.042 \\
\hline $10-15$ & $23.1(10.4)$ & $146(21.7)$ & 0.268 \\
\hline $15-20$ & $40.3(18.2)$ & $164(24.4)$ & 0.357 \\
\hline $20-25$ & $52.3(23.7)$ & $145(21.6)$ & 0.350 \\
\hline $25-30$ & $45.5(24.6)$ & $95(14.1)$ & 0.179 \\
\hline $30-35$ & $29.1(13.2)$ & $39(5.8)$ & 0.071 \\
\hline $35-40$ & $13.9(6.3)$ & $7(1.0)$ & 0.009 \\
\hline $40-45$ & $5.1(2.3)$ & $1(0.1)$ & 0.002 \\
\hline $45<$ & $2.0(0.9)$ & o( $\quad 0)$ & 0 \\
\hline
\end{tabular}


表 3 斜面方位別の出作り地の分布

\begin{tabular}{|c|c|c|c|}
\hline 料面方位 & $\begin{array}{l}\text { 面䅡 }\left(\mathrm{K} \mathrm{m}^{2}\right) \text { と } \\
\text { その割合 }(x)\end{array}$ & $\begin{array}{c}\text { 出作り地の数と } \\
\text { その封合 }(x)\end{array}$ & $\begin{array}{l}\text { 出作り地の } \\
\text { 面 }\left(\mathrm{K}^{2}\right)\end{array}$ \\
\hline 北 & $22.9(10.4)$ & $68(12.6)$ & 0.152 \\
\hline 北㫣 & $20.9(9.5)$ & $77(14.2)$ & 0.206 \\
\hline 東 & $24.1(10.9)$ & $93(17.2)$ & 0.221 \\
\hline 東南 & $21.6(9.8)$ & $66(12.2)$ & 0.204 \\
\hline 南 & $31.8(14.4)$ & $57(10.5)$ & 0.161 \\
\hline 南西 & $30.9(14.0)$ & $46(8.5)$ & 0.117 \\
\hline 西 & $36.5(16.5)$ & $70(12.9)$ & 0.195 \\
\hline 北西 & $32.4(14.7)$ & $64(11.8)$ & 0.144 \\
\hline
\end{tabular}

表 4 地質別の出作り地の分布

\begin{tabular}{|c|c|c|c|}
\hline 地 & $\begin{array}{l}\text { 面 }\left(\mathrm{K} \mathrm{m}^{2}\right) \leq \\
₹ の \text { 新合 }(x)\end{array}$ & 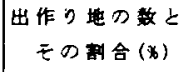 & $\begin{array}{l}\text { 出作り地の } \\
\text { 面 }\left(\mathrm{K} \mathrm{m}^{2}\right)\end{array}$ \\
\hline 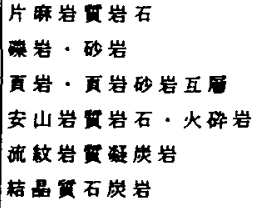 & $\begin{array}{r}13.4(6.1) \\
132.7(60.8) \\
23.9(11.0) \\
9.7(4.4) \\
9.3(4.3) \\
29.2(13.4)\end{array}$ & $\begin{array}{l}17(2.3) \\
161(51.6) \\
97(25.6) \\
21(7.2) \\
38(10.7) \\
13(2.6)\end{array}$ & $\begin{array}{l}0.032 \\
0.722 \\
0.359 \\
0.101 \\
0.150 \\
0.036\end{array}$ \\
\hline
\end{tabular}

表 5 土壤別の出作り地の分布

\begin{tabular}{|c|c|c|c|}
\hline \pm & $\begin{array}{l}\text { 面程 }\left(\mathrm{Km}^{2}\right) \text { と } \\
₹ \sigma \text { 部合 }(x)\end{array}$ & $\begin{array}{c}\text { 出作り地の数と } \\
\text { その到合 }(x)\end{array}$ & $\begin{array}{l}\text { 出作り地の } \\
\text { 面 }\left(\mathrm{K} \mathrm{m}^{2}\right)\end{array}$ \\
\hline 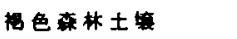 & $95.4(43.6)$ & $226(77.8)$ & 1.089 \\
\hline 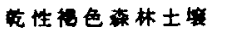 & $55.0(25.1)$ & $42(9.6)$ & 0.134 \\
\hline 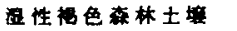 & $6.6(3.0)$ & $49(11.2)$ & 0.157 \\
\hline 湿性ボドソル化土培 & $15.9(7.3)$ & $1(0.4)$ & 0.005 \\
\hline 㟧石地 & $11.0(5.0)$ & $1(0,2)$ & 0.003 \\
\hline 性ポドンル北士壤 & $35.1(16.0)$ & $5(0.9)$ & 0.012 \\
\hline
\end{tabular}

表 6 植生別の出作り地の分布

\begin{tabular}{|c|c|c|c|}
\hline 植 & 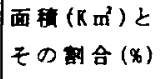 & $\begin{array}{c}\text { 出作り地の数と } \\
\text { その新合 }(x)\end{array}$ & $\begin{array}{l}\text { 出作り地の } \\
\text { 面蜻 }\left(\mathrm{x} \mathrm{m}^{2}\right)\end{array}$ \\
\hline 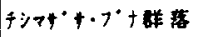 & $113.9(51.5)$ & $89(21.0)$ & 0.294 \\
\hline 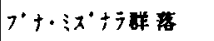 & $27.7(12.5)$ & $146(37.4)$ & 0.524 \\
\hline クリ・ミス゚ナラ群落 & $5.4(2.4)$ & $26(5.1)$ & 0.071 \\
\hline スギ・ヒノキ・ナワラ植林 & $6.6(3.0)$ & $110(26.4)$ & 0.370 \\
\hline 象の多い住宅地 & $0.5(0.2)$ & $6(0.4)$ & 0.005 \\
\hline 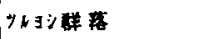 & $3.7(1.7)$ & $38(7.3)$ & 0.102 \\
\hline 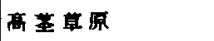 & $3.5(1.6)$ & $3(0.7)$ & 0.010 \\
\hline 自然地 & $2.9(1.3)$ & $8(1.6)$ & 0.022 \\
\hline 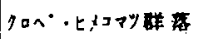 & $1.6(0.7)$ & $1(0.1)$ & 0.002 \\
\hline
\end{tabular}

表 7 植林別の出作り地の分布

\begin{tabular}{|c|c|c|c|}
\hline 植林 & $\begin{array}{l}\text { 面程 }\left(\mathrm{K} \mathrm{m}^{3}\right) \text { と } \\
\text { 七の部合 }(x)\end{array}$ & $\begin{array}{c}\text { 出作り地の就と } \\
\text { その合 }(x)\end{array}$ & $\begin{array}{l}\text { 出作り地の } \\
\text { 面㮴 }\left(\mathrm{K} \mathrm{m}^{2}\right)\end{array}$ \\
\hline 国有林 & $70.7(31.8)$ & $0(0)$ & 0 \\
\hline 保责林 & $75.5(34.0)$ & $138(34.8)$ & 0.425 \\
\hline 造林地 & $3.5(1.6)$ & $20(5.1)$ & 0.065 \\
\hline その他 & $72.3(32.6)$ & $238(60.1)$ & 0.910 \\
\hline
\end{tabular}

表 8 出作り地の適地

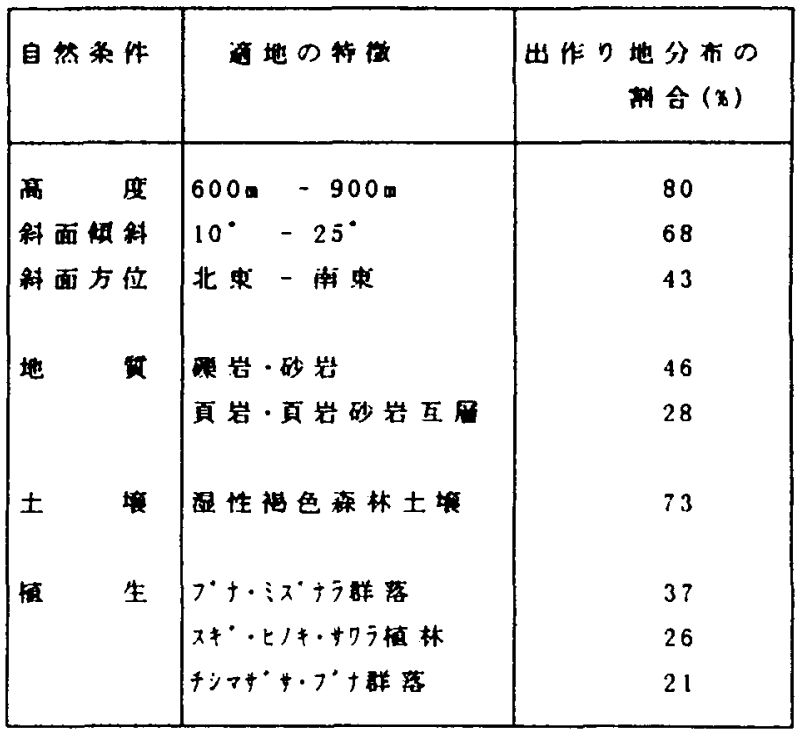

表 9 出作り跡地の植生

\begin{tabular}{|c|c|c|}
\hline 世作り跡地の值生 & $\begin{array}{c}\text { 出作り地の数と } \\
\text { ての制合 }\left(w^{\prime}\right)\end{array}$ &  \\
\hline ス丰徉落 & $165(51.2)$ & 0.703 \\
\hline 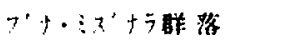 & $102(31.7)$ & 0.415 \\
\hline キシっザサ・ブナ睛落 & $32(9.9)$ & 0.150 \\
\hline 地地 & $9(2.8)$ & 0.071 \\
\hline 裸地 & $14(4.3)$ & 0.045 \\
\hline
\end{tabular}




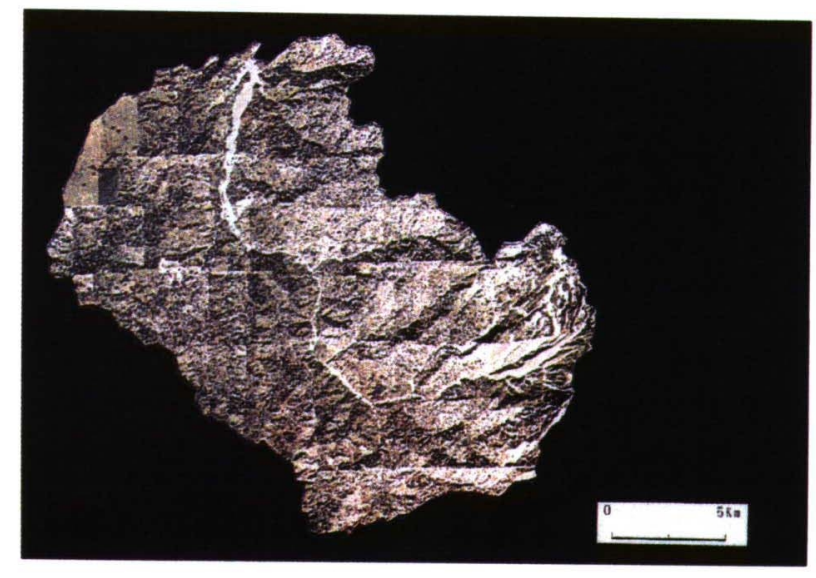

図 2 モザイクした空中写真と出作り地の重ね合わせ

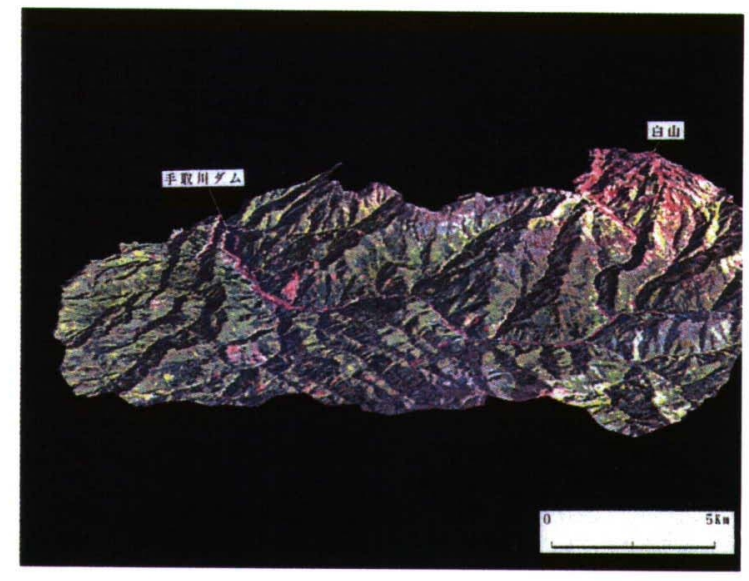

図３ワイヤネット処理したものに1987年10月の Landsat TMの画像をかぶせた3次元表示の画像、青は 水域、紫は自然裸地および都市地域、黄色は崩壊地、 緑は広葉樹林、濃い緑は針葉樹林を示す

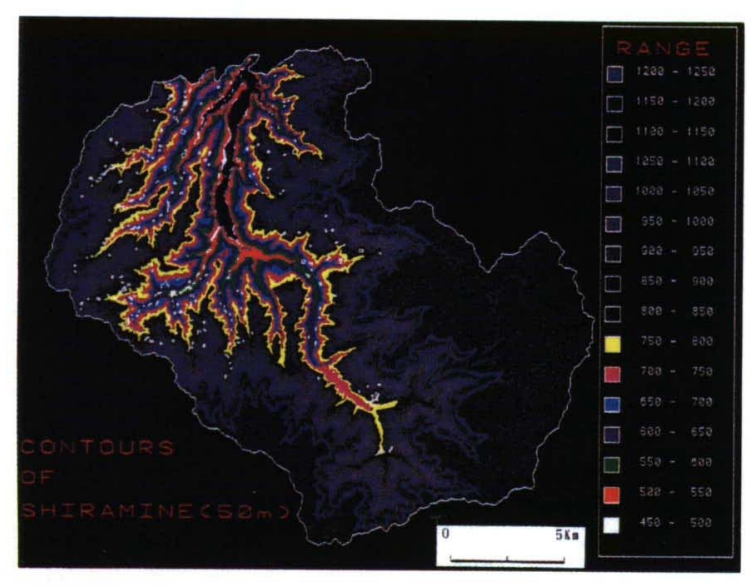

図 4 高度と出作り地の重ね合わせ

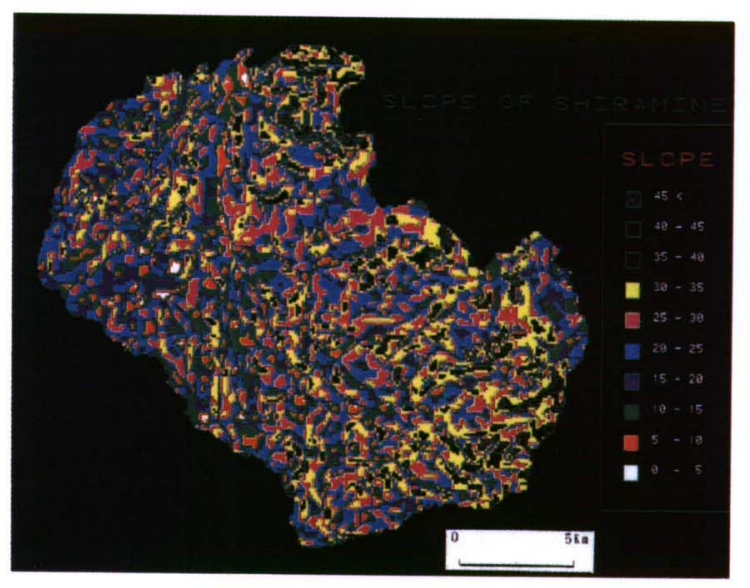

図 5 斜面㑯斜図

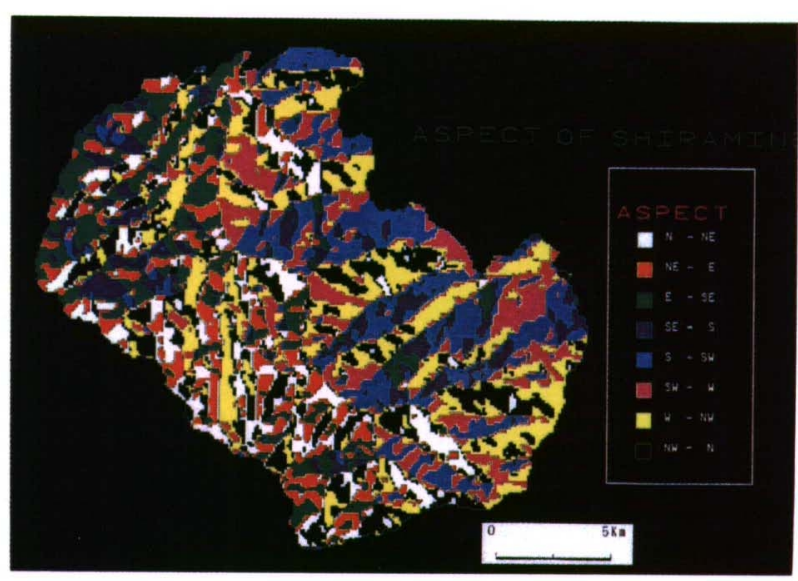

図 6 斜面方位図

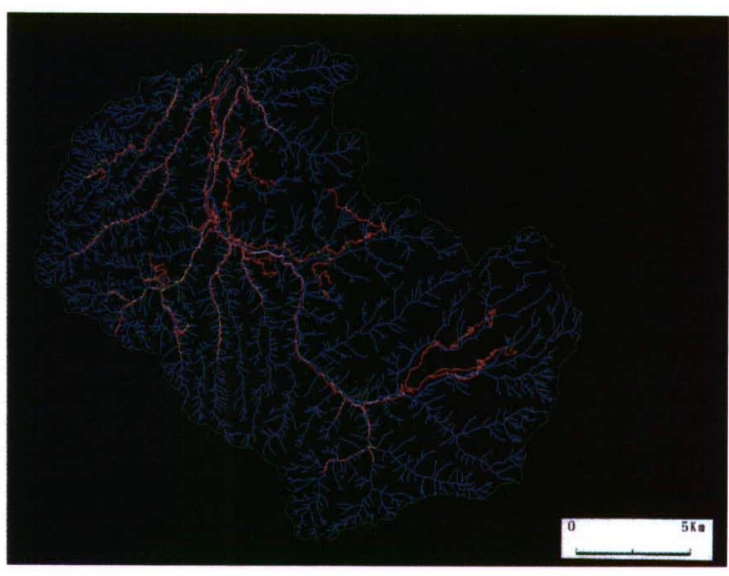

図 7 水系、林道、出作り地の重ね合わせ 


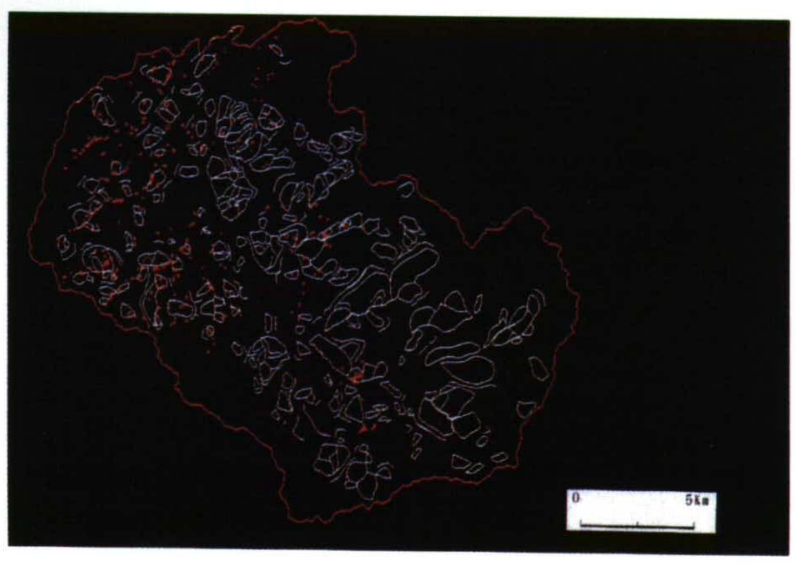

図８地すべり地と出作り地の重ね合わせ

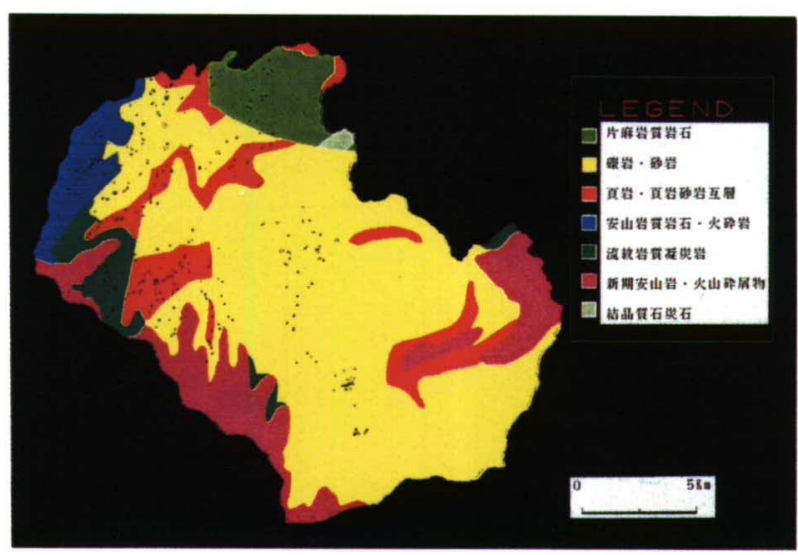

図 9 地質と出作り地の重ね合わせ

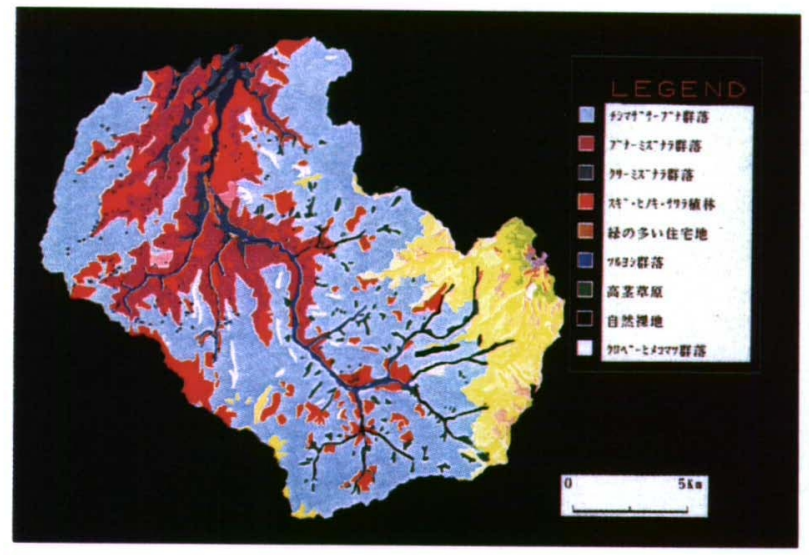

図11 植生と出作り地の重ね合わせ

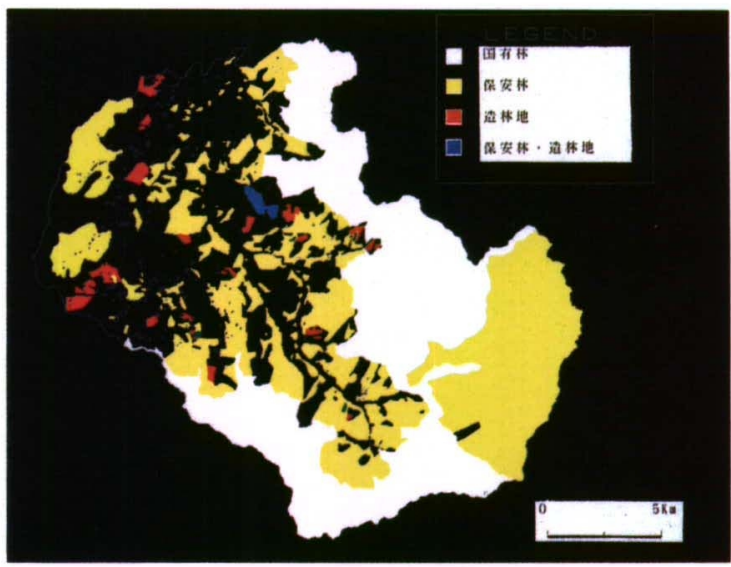

図12 植林と出作り地の重ね合わせ

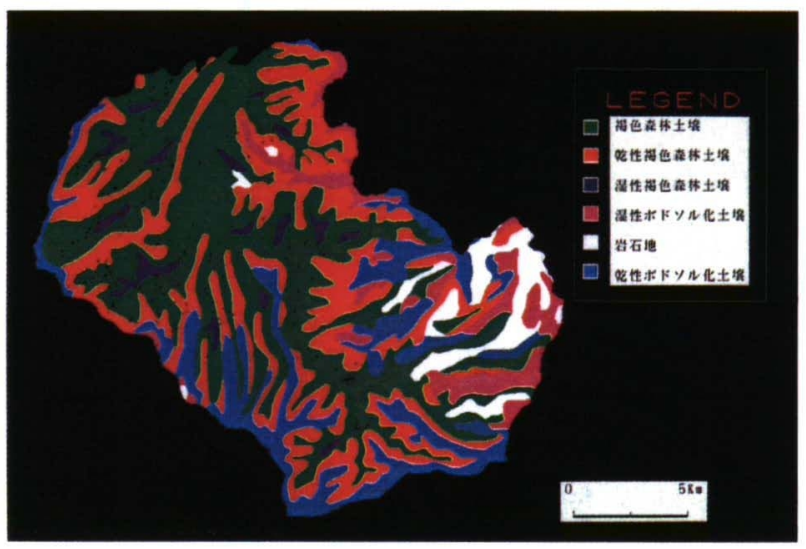

図10 土塎と出作り地の重ね合わせ 